\title{
HIV, syphilis, and viral hepatitis among Latin American indigenous peoples and Afro-descendants: a systematic review
}

\author{
Nancy K. Russell, ${ }^{1}$ Kevin Nazar, ${ }^{2}$ Sandra del Pino, ${ }^{3}$ Monica Alonso \\ Gonzalez, ${ }^{3}$ Ximena P. Díaz Bermúdez, ${ }^{4}$ and Giovanni Ravasi ${ }^{3}$
}

Suggested citation Russell NK, Nazar K, del Pino S, Alonso Gonzalez M, Díaz Bermúdez XP, Ravasi G. HIV, syphilis, and viral hepatitis among Latin American indigenous peoples and Afro-descendants: a systematic review. Rev Panam Salud Publica. 2019;43:e17. https://doi.org/10.26633/RPSP.2019.17

ABSTRACT Objective. To identify and summarize existing literature on the burden of HIV, sexually transmitted infections (STIs), and viral hepatitis (VH) in indigenous peoples and Afrodescendants in Latin America to provide a broad panorama of the quantitative data available and highlight problematic data gaps.

Methods. Published and grey literature were systematically reviewed to identify documents published in English, Spanish, or Portuguese with data collected between January 2000 and April 2016 on HIV, STI, and VH disease burden among indigenous peoples and Afrodescendants in 17 Latin American countries.

Results. Sixty-two documents from 12 countries were found. HIV prevalence was generally low $(<1 \%)$ but pockets of high prevalence $(>5 \%)$ were noted in some indigenous communities in Venezuela (Warao) (9.6\%), Peru (Chayahuita) (7.5\%), and Colombia (Wayuu females) (7.0\%). High active syphilis prevalence (> 5\%) was seen in some indigenous communities in Paraguay (11.6\% and 9.7\%) and Peru (Chayahuita) (6.3\%). High endemicity (> 8\%) of hepatitis B was found in some indigenous peoples in Mexico (Huichol) (9.4\%) and Venezuela (Yanomami: 14.3\%; Japreira: $29.5 \%$ ) and among Afro-descendant quilombola populations in Brazil (Frechal: 12.5\%; Furnas do Dionísio: 8.4\% in 2008, 9.2\% in 2003).

Conclusions. The gaps in existing data on the burden of HIV, STIs, and VH in indigenous peoples and Afro-descendants in Latin America highlight the need to 1) improve national surveillance, by systematically collecting and analyzing ethnicity variables, and implementing integrated biobehavioral studies using robust methodologies and culturally sensitive strategies; 2) develop a region-wide response policy that considers the needs of indigenous peoples and Afro-descendants; and 3) implement an intercultural approach to health and service delivery to eliminate health access barriers and improve health outcomes for these populations.

Keywords HIV; sexually transmitted diseases; syphilis; hepatitis, viral, human; health of indigenous peoples; Latin America.

\footnotetext{
Consultant, Pan American Health Organization, Washington, D.C., United States of America. Send correspondence to: Nancy K. Russell, nc3russell@
} yahoo.com

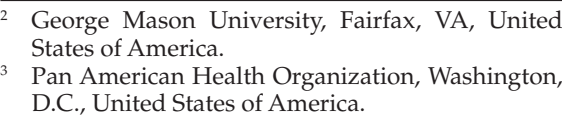

George Mason University, Fairfax, VA, United States of America.

3 Pan American Health Organization, Washington, D.C., United States of America.

Public Health Department, University of Brasília, Brasília, D.F., Brazil. 
Disparities in socioeconomic and health indicators have been reported for indigenous peoples and Afro-descendants in Latin America compared to available benchmarks (1). Concerns have been raised about the vulnerability of these populations to HIV, sexually transmitted infections (STIs), and viral hepatitis (VH). In response, the United Nations (UN) General Assembly made a formal commitment to eliminate barriers to HIV services, including stigma and discrimination in health care settings, and ensure engagement of indigenous communities (2).

Few countries collect disease surveillance data disaggregated by ethnicity, and previous literature reviews on this topic recognized that data on HIV, STIs, and $\mathrm{VH}$ in indigenous peoples and Afrodescendants are limited (3-5). In fact, although HIV, STIs, and VH are responsible for a significant burden of disease in Latin America (6-9), little is known about the burden of these infections among the nearly 50 million indigenous peoples (10) and over 110 million Afro-descendants (11) that reside there. The paucity of quantitative and qualitative data remains a barrier to understanding their health situation and the underlying health determinants.

The socioeconomic and health access disadvantages experienced by indigenous peoples and Afro-descendants stem from many factors, including geographic isolation and discrimination (12-14). In addition, economic disparities resulting from globalization have increased migration, amplifying the exposure of these communities to new infections $(15,16)$. Some advancements in establishing land rights and access to adequate health care for indigenous peoples have occurred (17), but not all Latin American governments have ratified these treaties (18-20).

The UN Agenda for Sustainable Development and the World Health Organization (WHO) Global Health Sector Strategies (2016-2021) for HIV, STIs and VH (20-23) commit to ending these epidemics as public health threats by 2030 . To that end, it is critical that the potential vulnerabilities of indigenous peoples and Afro-descendants in Latin America be further assessed. More complete information on the burden of disease of $\mathrm{HIV}$, STIs, and VH in these populations is needed for evidence-based decisions and the development of an effective regional response. This systematic review aimed to identify and summarize existing literature on the burden of HIV, STIs, and $\mathrm{VH}$ in indigenous peoples and Afro-descendants in Latin America to provide a broader panorama of the quantitative data available and highlight problematic data gaps.

\section{MATERIALS AND METHODS}

\section{Information sources and search strategy}

This systematic review was conducted according to the PRISMA guidelines (24). The search involved both electronic and manual strategies. Documents containing disease burden data on HIV, STIs, and $\mathrm{VH}$ from original prevalence studies or national surveillance case-based reporting systems were included. The populations under study were indigenous peoples and Afro-descendants in 17 Latin American countries (Argentina, Bolivia, Brazil, Chile, Colombia, Costa Rica, Ecuador, El Salvador, Guatemala, Honduras, Mexico, Nicaragua, Panama, Paraguay, Peru, Uruguay, and Venezuela). Review criteria for indigenous status were widely interpreted and included the following: self-identified, provideridentified, indigenous language spoken in the home, and/or majority (> 50\%) of a rural population.

Documents published in English, Spanish, or Portuguese with data collected between 1 January 2000 and 15 April 2016 were reviewed for inclusion. The following databases were systematically searched: PubMed (Medline), SciELO (Scientific Library Online), and LILACS (Latin American and Caribbean Center on Health Sciences Information). The following terms were cross-referenced: 1) acquired immune deficiency syndrome, HIV, sexually transmitted diseases, STI, syphilis, or viral hepatitis; 2) indigenous, native, ethnic distribution, Amerindian, Afro-descendant, Afro-Brazilian, or Afro-Colombian; and 3) Latin America, South America, Central America or $<$ name of specific country $>$. The manual search methodology included: 1) bibliography of review articles and theses found in the automated search; 2) abstracts from International AIDS Society (IAS) conferences ${ }^{5}$ and other international conferences on HIV, STIs, and VH among indigenous peoples and Afro-descendants; 3) databases

\footnotetext{
http://www.abstract-archive.org/
}

from health ministries and institutes; 4) contact with indigenous peoples and Afro-descendant organizations to obtain health indicator reports and studies; 5) contact with UN and other international cooperation agencies involved with health of indigenous and Afro-descendant peoples in search of documents in their databases; 6) documents related to indigenous peoples and HIV in the UN Permanent Forum on Indigenous Issues, the UN Special Rapporteur on the rights of indigenous peoples, and the UN Expert Mechanism on the Rights of Indigenous Peoples. The automated search identified 181 documents and the manual search identified 307 documents (137 from grey literature, 62 from bibliographical review, and 108 from IAS abstracts). The selection process is shown in Figure 1.

\section{Data extraction}

The information extracted included author, title, publication name, publication type, date of publication, location of study, population characteristics (including sex and age), name of ethnic group(s), sample size, date of data collection, objective of study, sampling methods, disease burden (numerator and denominator for prevalence), disease screening method, limitations, and findings and recommendations. Document review and disease burden data extraction were performed by two researchers (NKR and KN). Concordance was achieved on $94 \%$ of values and all discrepancies were checked with original documents and resolved. Meta-analysis was not considered due to heterogeneity of methods, variation in years of data collection, and differing social/cultural contexts across populations.

\section{RESULTS}

A total of 62 documents (64 records) were identified by the systematic review. One document was published in 2017 with data previously obtained via personal communication with the authors (16). About one-third (20 documents) came from Brazil, with Peru and Colombia accounting for another one-fourth $(25.8 \%)$. No documents were identified from Costa Rica, Ecuador, El Salvador, Nicaragua, or Uruguay. More than half (34 documents) were journal articles, 14 were government reports, eight were 
FIGURE 1. Flow diagram for document search and selection process in a systematic review of scientific literature with disease burden data on HIV, syphilis, and viral hepatitis among Latin American indigenous peoples and Afro-descendants collected between 1 January 2000-15 April 2016

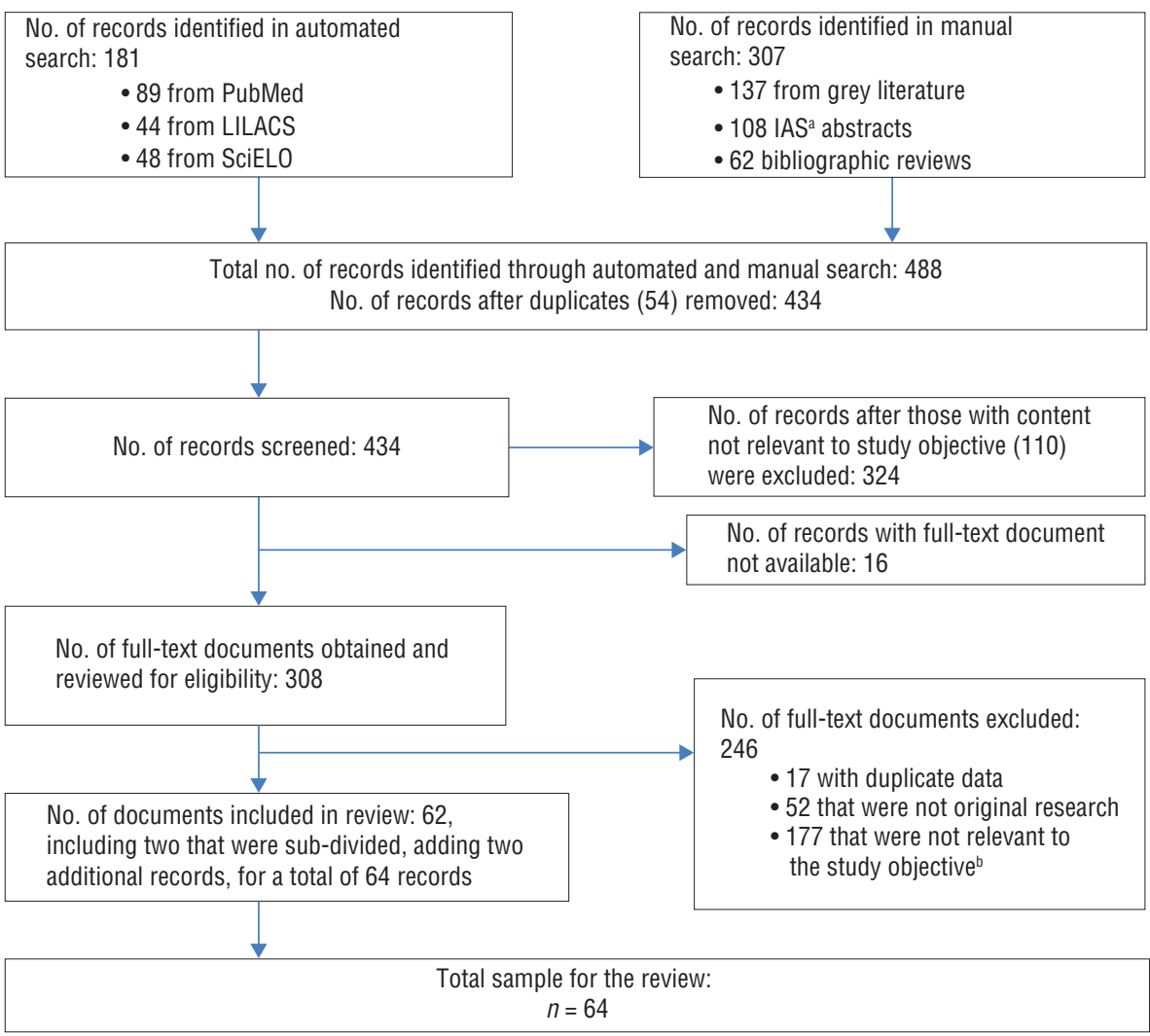

Source: Prepared by the authors based on the study results.

a IAS: International AIDS Society.

b Including 118 KAP (knowledge, attitude, and practices) and prevention documents not screened out earlier due to broader research objective at outset of review.

published abstracts, and six were other types of documents.

A total of $46(74 \%)$ of the documents reported disease prevalence data from original studies, with the rest (16) reporting case report data. Documents that reported prevalence data from the same study sample were merged into a single record, resulting in 39 unique prevalence studies.

\section{Burden of HIV in indigenous peoples and Afro-descendants}

HIV prevalence data were available from 17 studies, including 15 conducted with indigenous peoples and two with Afro-descendants (Garifuna, Honduras) (16, 25-40). Figure 2 shows HIV prevalence data from these 17 studies compared to UNAIDS estimates for the general population (41). Prevalence ranged from zero to $9.6 \%$. Using $\mathrm{WHO}$ definitions for concentrated epidemics females, especially in the 2014 study when rural males $(1.6 \%)$ were compared to rural females $(4.9 \%)$, yet this difference was not significant (29).

The review also identified 14 documents with HIV / AIDS case reporting or associated mortality data among indigenous peoples and Afro-descendants from six countries (47-60). Data from 10 of 11 documents reporting HIV / AIDS surveillance data are presented in Table 1. In most cases, the data were reported as raw numbers and "percent of all HIV/ AIDS cases," and these percentages were compared to official census data for each ethnic group within their respective countries $(10,61)$. One document provided case reporting data on indigenous peoples from the Mato Grosso do Sul region of Brazil without providing the total number of cases for that region; these data were left out of the table (60). The only ethnic group found to be overrepresented in terms of HIV / AIDS cases was the Kuna Yala in Panama, who presented an HIV infection rate nearly double that of the general population (234.9/100 000 versus 130.8/100 000 respectively) (56).

In the three documents reporting mortality data (57-59), only two had notable findings. A report from Panama suggested the Ngäbe Buglé peoples are overrepresented in terms ofHIV/AIDS-associated deaths (accounting for $4.9 \%$ of the population and $7.2 \%$ of HIV / AIDS-associated deaths) (59). A study from Chile reported an adjusted mortality rate attributed to HIV of 10.8/100 000 among the Aymara (in Arica and Parinacota) compared to 4.2/100 000 among non-Aymara between 2004 and $2006(57)$. This rate rose to 11.2/100 000 from 2007 to 2009 (compared to 4.1 among non-Aymara).

Vulnerable groups. The availability of data on the burden of HIV / AIDS in pregnant indigenous and Afro-descendant women in Latin America was very limited, and evidence of a low burden $(<1 \%$ prevalence) was observed in two prevalence studies from Brazil $(0.07 \%)$ and Peru $(0.16 \%)(16,36)$. Case reporting data from Brazil also indicated that pregnant indigenous women with HIV represent $0.3 \%$ of cases, comparable to the $0.5 \%$ that indigenous people account for in Brazil's population (51). Data on the burden of HIV among indigenous and Afrodescendant youth and children were limited to three documents. The data from one of the documents, a report from 
FIGURE 2. Data from 17 studies on HIV prevalence in indigenous peoples and Afro-descendants versus estimates for general population, ${ }^{a}$ Latin America, 2007-2017

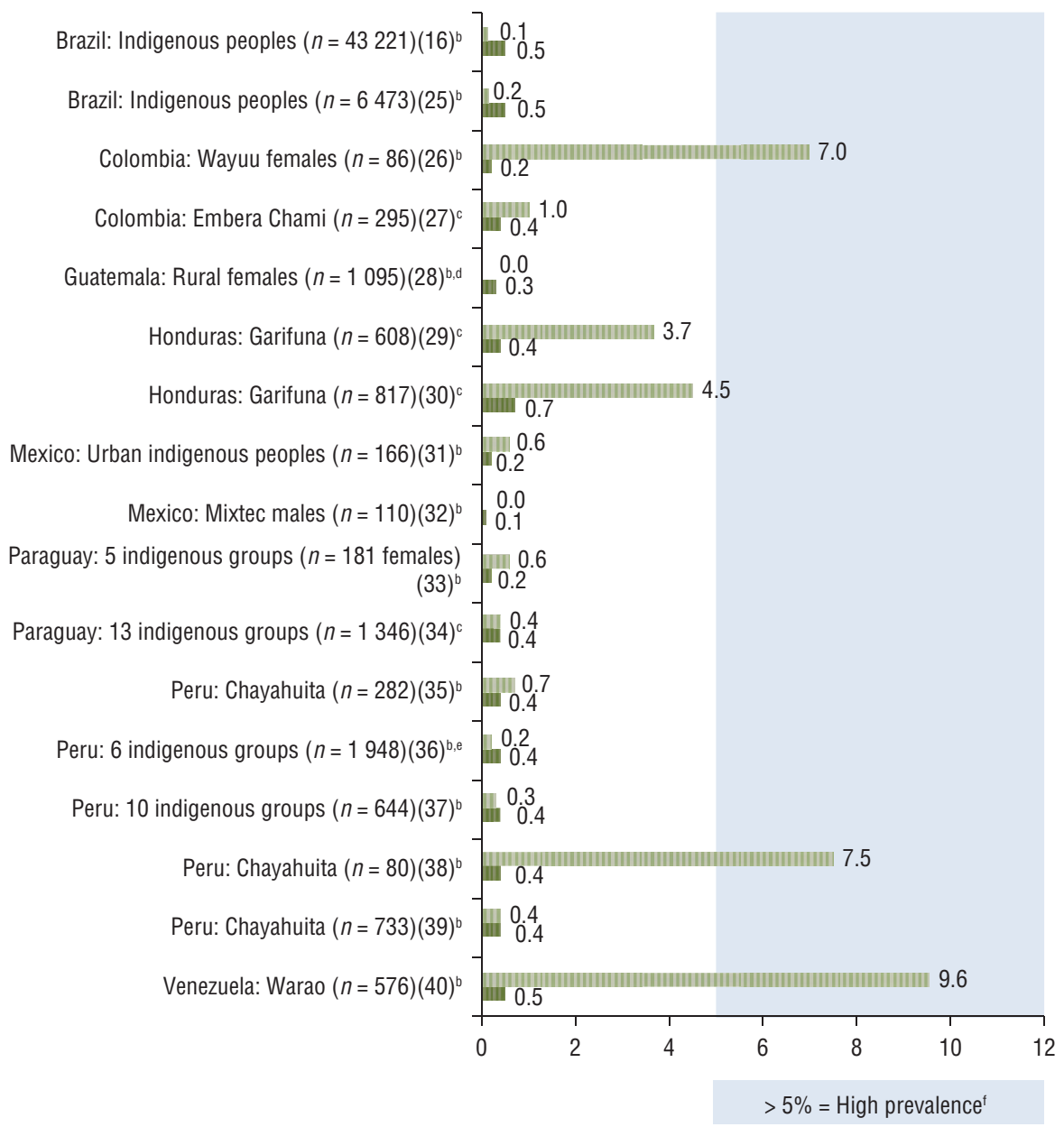

III HIV prevalence in indigenous peoples or Afro-descendants (\%)

III HIV prevalence in general population (\%)

Source: Prepared by the authors based on the study results and published data.

a UNAIDS HIV prevalence data closest in year/sex/age (41).

${ }^{\mathrm{b}}$ Non-probability sampling methods used.

c Probability sampling methods used.

d Indigenous people made up $52 \%$ of the study population.

e Pregnant women and their current sexual partner.

${ }^{f}$ Based on WHO threshold (42).

the Guatemalan government (54), is shown in Table 1. The other two documents included a report on a small study in Peru that found no cases of HIV among Chayahuita residents under age 15 (38) and a Brazilian government document that reported 11 cases of HIV among indigenous youth in 2003 (49). No data were found on HIV prevalence among key populations, such as men who have sex with men (MSM) and sex workers.

\section{Burden of syphilis in indigenous peoples and Afro-descendants}

Data on the burden of STIs (other than HIV) were available from 26 documents from eight countries. All but one of the 26 documents on STIs reported data on syphilis; only nine included data on other STIs. Given the preponderance of syphilis data, this review focused on the burden of syphilis. Three documents contained case reporting and 22 had prevalence data from 16 unique studies (two studies in Afro-descendants and the rest in indigenous groups). Of these 16 studies, eight used non-treponemal tests combined with confirmatory treponemal tests to establish active infection (range: $0.5 \%-11.6 \%)(29-30,33-36,38,39)$; four used treponemal rapid tests exclusively to determine the seroprevalence of syphilis (range: $1.6 \%-7.0 \%)(16,27,62,63)$; one study used a non-treponemal test exclusively (0\%) (64); and three studies did not report their testing method $(28,31,37)$. Figure 3 compares the data from the eight studies on active syphilis with national benchmarks (65), showing higher syphilis prevalence in indigenous peoples and Afro-descendants in all eight studies. Using WHO's threshold of $5 \%$ of active syphilis for identifying high prevalence settings (42), two studies of indigenous groups in Paraguay $(33,34)$ suggested the existence of high prevalence of active syphilis. One study of a peri-urban Chayahuita village in Peru (38) also found high prevalence of active syphilis, but the two follow-up studies conducted with Chayahuita (in more remote villages, and with larger sample sizes) did not confirm this finding, suggesting the high prevalence detected was limited to the one village $(35,39)$.

Vulnerable groups. The review identified six documents (four unique studies $(16,36,62,66))$ containing data on the burden of syphilis in pregnant indigenous women from Bolivia, Brazil, and Peru. One of the two studies in Brazil took place in nine Special Indigenous Health Districts $(n=4144)$ in the Amazon area with treponemal seroprevalence averaging $1.52 \%$ (range: $0 \%$ in Médio Purus and Parintins to $3.38 \%$ in Vale do Javari) (16). The other, a national, hospital-based study among postpartum women $(n=23894)$, found a lower percentage of indigenous women infected $(0.55 \%)$ versus the general population $(1.02 \%)$, but this difference was not significant, and a broad definition of syphilis diagnosis was used (66). The study in Bolivia detected a treponemal seroprevalence of $7 \%$ in 2004-2005 in a large convenience sampling clinic-based study of pregnant women $(n=2873)$ who spoke only indigenous language, or Spanish and some indigenous language (62). The 2012 study in the Peruvian Amazon was another large convenience sample $(n=1$ 248 ) that covered pregnant indigenous women and found $1.6 \%$ prevalence of active syphilis (36).

Case reporting data of active syphilis in pregnant women were also available from Brazil and showed that indigenous women accounted for $2.0 \%$ of all reported cases between mid-2005 and 2010 (50) and were therefore proportionately overrepresented, given that indigenous peoples account for $0.5 \%$ of Brazil's 
TABLE 1. Data from HIV case reporting in indigenous peoples and Afro-descendants, Latin America, 2005-2015

\begin{tabular}{|c|c|c|c|c|c|}
\hline $\begin{array}{l}\text { Geographic area } \\
\text { (reference) }\end{array}$ & $\begin{array}{l}\text { Ethnic origin of } \\
\text { population }\end{array}$ & $\begin{array}{c}\text { Country prevalence } \\
(\%) \text { of given ethnic } \\
\text { origin }^{\text {a }}\end{array}$ & $\begin{array}{l}\text { No. of HIV cases } \\
\text { ( } \% \text { of total } \\
\text { reported cases) }\end{array}$ & $\begin{array}{l}\text { Year(s) of data } \\
\text { collection }\end{array}$ & Type of data \\
\hline Bolivia (47) & Araona, Aymara & 41 & $550(21.6)$ & 2012 & CRVIR ${ }^{\mathrm{b}}$ HIV/AIDS surveillance ( $n=2544$ cases) \\
\hline El Alto, Bolivia (48) & Aymara, Quechua & 41 & $53(38)$ & 2012 & CRVIR HIV/AIDS surveillance ( $n=139$ cases) \\
\hline Brazil (49) & Indigenous & 0.5 & $100(0.3)$ & Until 2003 (cumulative) & National AIDS surveillance \\
\hline Brazil (50) & Indigenous & 0.5 & $53(0.29)$ & 2009 & National AIDS surveillance \\
\hline Brazil (51) & Indigenous & 0.5 & $58(0.26)$ & 2014 & National AIDS surveillance \\
\hline Brazil (51) & Indigenous & 0.5 & $65(0.3)$ & 2014 & National HIV surveillance \\
\hline Colombia (52) & Indigenous & 3.4 & $81(1.1)$ & 2010 & National HIV surveillance data ( $n=7490$ cases) \\
\hline Colombia (52) & Afro-Colombian & $10.6^{c}$ & $503(6.7)$ & 2010 & National HIV surveillance data ( $n=7490$ cases) \\
\hline Guatemala $(53,54)$ & Maya, Garifuna, Xinca & 60 & $3510(23.1)$ & 2004-2010 (cumulative) & National HIV surveillance data ( $n=15195$ cases) \\
\hline Guatemala (55) & Maya, Garifuna, Xinca & 60 & $\begin{array}{l}\text { HIV: } 393(24.3) \\
\text { AIDS: } 616(24.9)\end{array}$ & $\begin{array}{l}\text { Aug 2003-Aug } 2005 \\
\text { (cumulative) }\end{array}$ & $\begin{array}{l}\text { National surveillance data ( } n=1619 \text { HIV cases; } \\
2478 \text { AIDS cases) }\end{array}$ \\
\hline \multirow[t]{3}{*}{ Guatemala (54) } & Maya: & 60 & $179(22.3)$ & 2004-0ct 2009 & \multirow{3}{*}{$\begin{array}{l}\text { National surveillance data ( } n=814 \text { HIV cases, } \\
\text { age } 5-19 \text { years) }\end{array}$} \\
\hline & Garifuna: & & $5(0.62)$ & & \\
\hline & Xinca: & & $2(0.25)$ & & \\
\hline Panama (56) & Kuna Yala & $N A^{d}$ & $85(234.9 / 100000)$ & 2001-2008 (cumulative) & $\begin{array}{l}\text { National HIV surveillance data crossed with } 2004 \\
\text { census }\end{array}$ \\
\hline Panama (56) & Ngäbe Buglé & NA & $9(7.0 / 100000)$ & 2001-2008 (cumulative) & $\begin{array}{l}\text { National HIV surveillance data crossed with } 2004 \\
\text { census }\end{array}$ \\
\hline
\end{tabular}

Source: Prepared by the authors based on the study results and published data.

a $(10)$.

${ }^{\mathrm{b}}$ Centro Regional de Referencia, Información y Vigilancia.

c $(61)$.

NA: not applicable.

FIGURE 3. Data from 8 studies on prevalence of active syphilis ${ }^{\mathrm{a}}$ in indigenous peoples and Afro-descendants versus benchmark proxy, ${ }^{\mathrm{b}}$ Latin America, 2007-2014

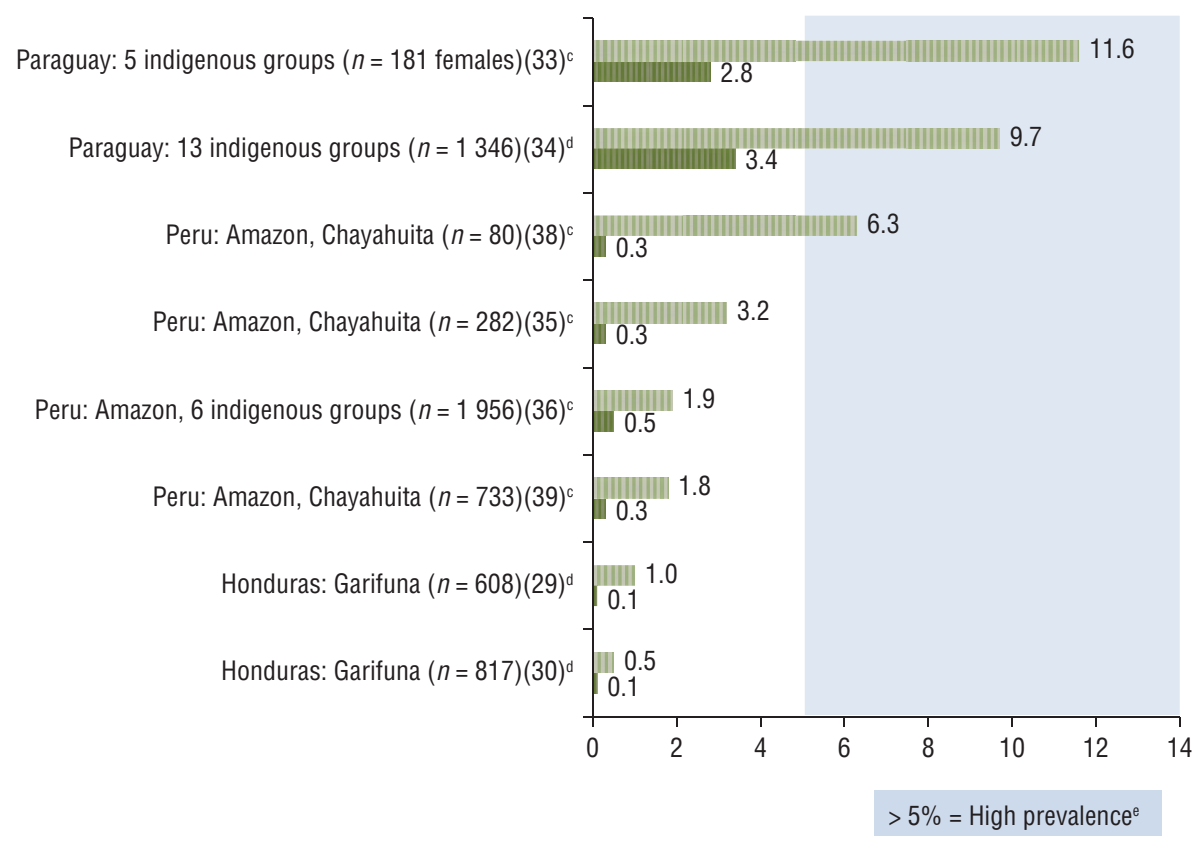

III Active syphilis (\%) il| Benchmark proxy (\%)

Source: Prepared by the authors based on the study results and published data.

a Based on non-treponemal tests combined with confirmatory treponemal tests.

${ }^{b}$ Comparison data extracted from Pan American Health Organization country reports using best proxy available in terms of date, population, and testing method (65).

c Non-probability sampling methods used.

Probability sampling methods used.

e Based on WHO threshold (42). population. Data on congenital syphilis were very limited. A Brazilian government report reporting 17 cases of congenital syphilis among indigenous peoples between 2000 and 2005 noted this as evidence of failure of prenatal service coverage of indigenous women (49). Out of concern that this low number of cases may reflect limited access to health services, a feasibility study for rapid syphilis testing was conducted in an indigenous Amazonian community $(n=282)$ and two cases of congenital syphilis were reported among the 19 cases of syphilis detected (63).

\section{Burden of viral hepatitis in indigenous peoples and Afro-descendants}

This review identified 25 documents containing data on $\mathrm{VH}$ in indigenous peoples and Afro-descendants from seven Latin American countries (Argentina, Brazil, Colombia, Guatemala, Mexico, Peru, and Venezuela). Of these 25 documents, two only reported data on hepatitis A $(67,68)$ and one only covered hepatitis G (GB virus C) (69) and were not further analyzed. Of the remaining 22 documents, 21 unique studies were 
identified, with 18 reporting data on prevalence of hepatitis B, six on hepatitis C, and four on hepatitis D.

Although tests for measuring the prevalence of hepatitis B varied, most studies reported both hepatitis B surface antigen (HBsAg), ranging from zero to $29.5 \%$, and antibodies to hepatitis B core (anti-HBc), ranging from zero to $78 \%$. Among the 18 studies reporting hepatitis B prevalence, six were conducted with Afro-Brazilians and the remaining 12 with indigenous groups. Figure 4 shows data from 16 of the 18 studies
(27, 36, 70-83) that reported HBsAg prevalence in indigenous peoples and Afro-descendants in Argentina, Brazil, Colombia, Mexico, Peru, and Venezuela compared to Center for Disease Analysis (Lafayette, Colorado, USA) 2016 estimates of HBsAg for each country, and standardized definitions of endemicity (9). The two studies not included in Figure 4 were left out due to a small sample size (84) and a sample of children under 5 (85). All studies of Afro-Brazilian populations and nearly all studies of indigenous groups reported
HBsAg prevalence values exceeding the level in the general population. Furthermore, this review identified studies reporting high endemicity (> $8 \%$ ) in the following areas: Mato Grosso do Sul and Maranhão, Brazil (Afro-Brazilians) (73, 76, 78); Amazonas, Colombia (79); Nayarit, Mexico (Huichol) (81); and Amazonas and Zulia, Venezuela (Yanomami and Japreira, respectively) $(82,83)$. Areas of intermediate endemicity $(2 \%-8 \%)$ were detected in the Amazon regions in Colombia (80), Peru (36), and Venezuela (82).

FIGURE 4. Prevalence of hepatitis B surface antigen in indigenous peoples and Afro-descendants compared to national estimates ${ }^{a}$ in Latin America, 2003-2015

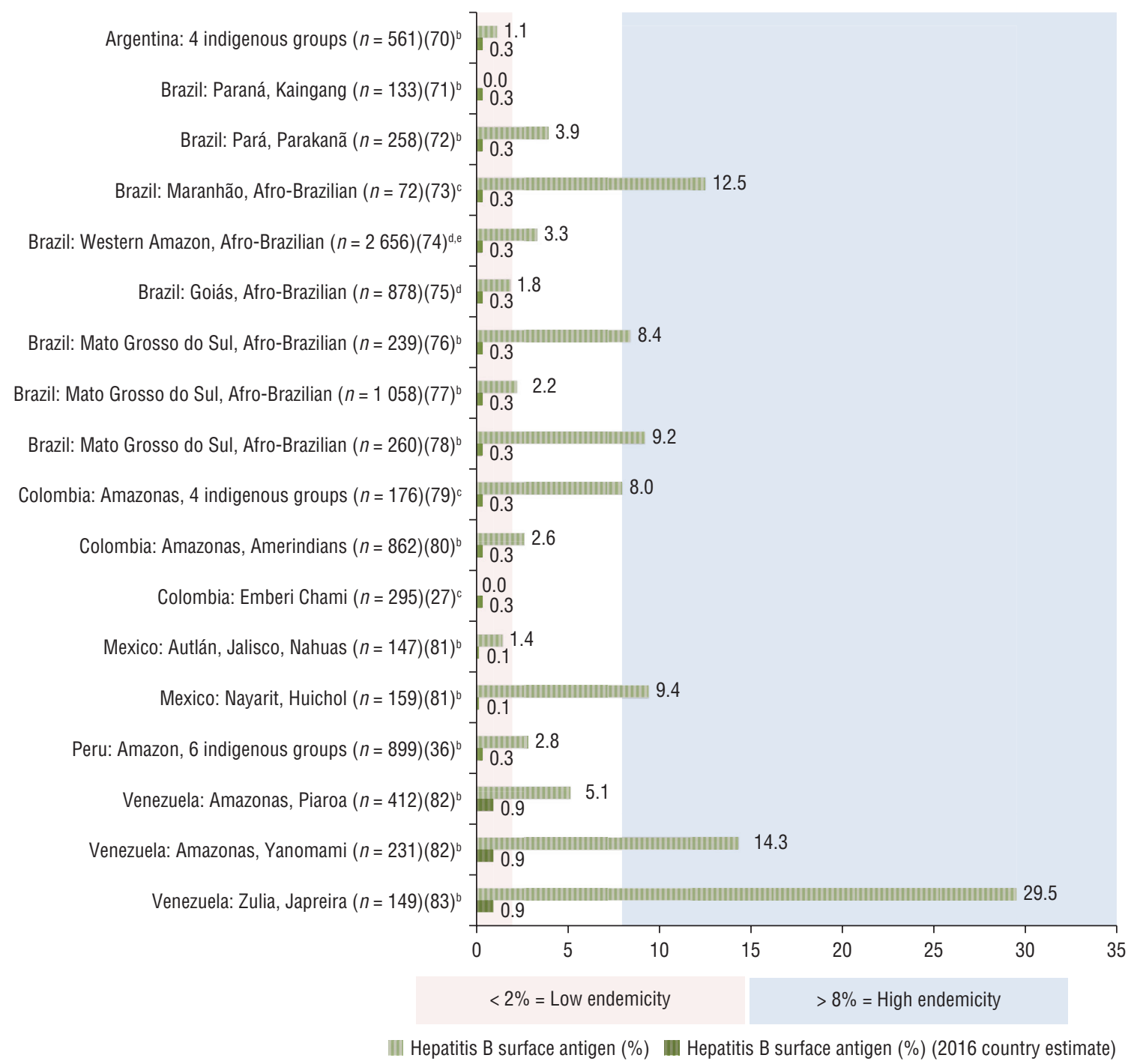

Source: Prepared by the authors based on the study results and published data.

a (9).

b Non-random sampling methods used.

c Sampling methods not reported.

' Random sampling methods used.

e Afro-Brazilians accounted for $71.5 \%$ of population. 
The review found only one study containing data on hepatitis B in indigenous children under age 5 (85). The study found zero HBsAg prevalence and a low anti-HBc prevalence, suggesting low endemicity among young children in the Peruvian Amazon.

Six studies were found that reported the prevalence of antibodies to hepatitis $\mathrm{C}$ virus (anti-HCV), with a range of zero to $5.7 \%$ (three from Brazil $(64,71,86)$ and one each from Colombia (79), Mexico (31), and Paraguay (84)). Overall, the prevalence of hepatitis C was low, apart from the studies in Colombia (prevalence of $5.7 \%$ in Amazonas) and Mexico (prevalence of $4.2 \%$ among indigenous peoples from 12 urban areas).

The review identified four studies reporting on the prevalence of antibodies to hepatitis D virus (anti-HDV) from Brazil (residents of Acre) (74); Colombia (two studies in indigenous groups from Amazonas) $(79,80)$; and Venezuela (indigenous peoples from Amazonas) (82). Overall anti-HDV prevalence ranged from $0.1 \%$ (in Venezuela) (82) to $8.3 \%$ (in Colombia) (79). In addition, three of these studies reported the prevalence of anti-HDV in HBsAg carriers, which ranged from $6.0 \%$ to $43.5 \%$, clearly identifying a potential added risk of fulminant hepatitis and more severe progression to chronic liver disease in these populations due to HDV superinfection.

\section{DISCUSSION}

Although the observed burden of HIV was generally low, potential pockets of high prevalence $(>5 \%)$ were noted among the Garifuna (Honduras), some Warao communities (Venezuela), some Chayahuita communities (Peru), and some Wayuu females (Colombia). In addition, national surveillance data suggest proportionately higher HIV detection in Kuna Yala (Panama), and HIV-related mortality in Ngäbe Buglé (Panama) as well as Aymara (Chile). Furthermore, an elevated prevalence of active syphilis compared to national benchmarks was seen in all indigenous and Afro-descendent groups for which data were found, including high prevalence of active syphilis in some groups in Paraguay (two studies, including 18 indigenous tribes) and Peru (Chayahuita). Likewise, moderate to high endemicity of hepatitis B was noted among some indigenous populations in Brazil, Colombia, Mexico
(Huichol), Peru, and Venezuela (Japreira, Piaroa, and Yanomami), and among various Afro-descendant quilombola ${ }^{6}$ in Brazil.

The vulnerability to HIV and STIs is further highlighted by findings related to the knowledge, attitude, and practices studied in indigenous peoples and Afrodescendants in Latin America. Indigenous peoples have reported lower knowledge about HIV, its transmission, and preventive practices (87-89), and higher risk behavior, such as lower condom use $(87,90,91)$, compared to national averages. In addition, indigenous and Afro-descendant females generally have exhibited lower knowledge about HIV transmission and prevention than men $(27,36,38,92,93)$, and reported lower usage of condoms $(29,36,44,90)$, and higher levels of forced sex; whereas males have reported more multiple sexual partnerships $(29,30,36,87)$ and lower exposure to HIV tests $(27,30,46)$.

Although a substantial amount of information was uncovered, many gaps were identified. Just six countries in Latin America were found to have case reporting or surveillance data on HIV and STIs disaggregated by ethnic origin (Bolivia, Brazil, Chile, Colombia, Guatemala, and Panama). Seroprevalence studies provide additional information, but no data were available for five countries (Costa Rica, Ecuador, El Salvador, Nicaragua, or Uruguay). Of more than 600 indigenous groups in Latin America (10), data were identified for only 66 named ethnic groups (some documents did not specify the names of the indigenous groups).

Additional data gaps were identified related to subgroups within indigenous peoples and Afro-descendants. Very little data were found on disease burden of HIV and syphilis among pregnant women and newborns (to monitor vertical transmission), which is concerning, considering the regional goal of eliminating mother-to-child transmission of HIV and syphilis (65).

Furthermore, no studies were found addressing the burden of HIV and STIs among indigenous or Afro-descendant MSM, sex workers, or drug users. Since the completion of this systematic review, one abstract was published on HIV in MSM in Guatemala that found HIV

Resident of a quilombo (Brazilian hinterland settlement founded by people of African origin). prevalence in indigenous MSM to be $4.8 \%$, highlighting the need for further investigation with this population (94).

This systematic review also uncovered many inconsistencies in methodologies used to study indigenous or Afro-descendant populations. The criteria for determining ethnic origin varied widely (e.g., language spoken at home, residing in an indigenous area, provider assignment, and self-identification), although the recommended standard is self-identification (17). The sampling methods also varied, with many studies using convenience samples, given the challenges of studying remotely located populations. Heterogeneity was also found in the methods used to detect diseases, particularly for syphilis.

These findings provide important and timely information for Latin American countries as they begin implementing the new regional Policy on Ethnicity and Health (95), and the authors propose a number of recommendations. First, it is critical that the evidence of higher burden be confirmed and monitored with robust and more standardized surveillance methodologies. HIV, STI, and VH surveillance systems that consistently track the ethnicity of cases need to be developed and applied in all countries, including for vertical transmission. Given the potential shortcomings of case reporting systems in detecting epidemics in remote locations (with less access to health services, screening, and case notification), triangulation of data from a variety of sources should be considered for more accurate monitoring. Studies should apply an ethical approach to research using culturally sensitive strategies, engaging local communities, and ensuring participation of indigenous peoples and Afro-descendants, both females and males $(96,97)$. Furthermore, an effort should be made to identify health determinants, cultural factors, beliefs (e.g., traditional concepts of health and disease), and behaviors (e.g., MSM activity, sex work or transactional sex, alcohol and substance abuse, migration, etc.) within indigenous and Afro-descendant communities that elevate risk.

Second, HBV immunization programs need to be integrated with maternal and neonatal services, particularly in more remote areas, to address gaps in coverage of $\mathrm{HBV}$ birth dose vaccination (within the 
first 24 hours) that have been documented in the Peruvian and Colombian Amazon areas, possibly related to the low rate of facility-based delivery in certain indigenous communities (98). These services should include community-based outreach activities to administer the first dose of HBV vaccine to newborns delivered at home.

Third, there is an urgent need for health promotion and HIV/STI preventive interventions that take advantage of new technologies and are nondiscriminatory, culturally sensitive, and respectful of gender differences. In particular, syphilis screening programs should be prioritized, utilizing point-of-care rapid testing and timely penicillin treatment of individuals with a reactive treponemal test, as recommended by WHO (42). These interventions should be developed using an intercultural approach to health, promoting coexistence, respect, and mutual acceptance between the culture of the conventional health system and local cultures through collaboration with the community, the family, and social leaders $(96,97)$.

Finally, with improved data, evidence-based policies and service delivery models can also be designed and implemented using an intercultural approach that considers different contexts, priorities, and needs. This is critical for the elimination of service access barriers and to improve the health outcomes of indigenous peoples and Afro-descendants.

\section{Limitations}

The findings of this review are qualified by its limitations. First, to minimize data gaps, the review included as many data sources as possible, including government reports and conference abstracts, but this limited the quality of the data discovered. Furthermore, the methodological inconsistencies in the included studies limited data comparability. Also, many of the studies relied on non-probability sampling, increasing the possibility of bias. Finally, although this review highlights certain areas and ethnic groups with elevated disease prevalence, the paucity of available data has led to an underrepresentation of many geographic areas and ethnic groups in Latin America. Therefore, caution is advised in making any generalizations across ethnic groups or countries given the lack of data, the potential for bias in existing studies, the diverse populations studied, and the specific cultural contexts within which each indigenous and Afrodescendant group lives.

\section{Conclusions}

Although current evidence suggests an overall low burden of HIV, pockets of high prevalence in some of the populations studied, combined with elevated levels of syphilis and HBV, warrant improving national surveillance systems with systematic collection and analysis

\section{REFERENCES}

1. Anderson I, Robson B, Connolly M, AlYaman F, Bjertness E, King A, et al. Indigenous and tribal peoples' health (The Lancet-Lowitja Institute Global Collaboration): a population study. Lancet. 2016;388(10040):131-57. http:// dx.doi.org/10.1016/S0140-6736(16) 00345-7

2. United Nations General Assembly. Political declaration on HIV and AIDS: on the fast-track to accelerate the fight against HIV and to end the AIDS epidemic by 2030. $70^{\text {th }}$ Session, Agenda Item 11. 2016 Jun 8. Points 62j, 64a. (A/Res/70266). Available from: http:// www.unaids.org/sites/default/files / media_asset/2016-political-declarationHIV-AIDS_en.pdf

3. Minichiello V, Rahman S, Hussain R. Epidemiology of sexually transmitted infections in global indigenous populations: data availability and gaps. Int J STD AIDS. 2013;24(10):759-68.
4. Garcia PJ, Bayer A, Cárcamo CP. The changing face of HIV in Latin America and the Caribbean. Curr HIV / AIDS Rep.

5. De Carvalho NS, Cho R, Flores LP. DST em crítica e revisão da literatura DST. J Bras Doenças Sex Transm. 2011; 23(3):142-5.

6. Joint United Nations Programme on HIV/ AIDS. Prevention gap report 2016. Geneva: UNAIDS; 2016. Available from: http:// www.unaids.org/sites/default/files/ media_asset/2016-prevention-gap-report en.pdf

7. Joint United Nations Programme on HIV/AIDS. The gap report 2014. Geneva: UNAIDS; 2014. Available from: http:// files.unaids.org/en/media/unaids/contentassets / documents / unaidspublication/2014/UNAIDS_Gap_report_en.pdf

8. World Health Organization. Global incidence and prevalence of selected curable sexually transmitted infections - 2008 . 2014;11(2):146-57. populações indígenas no Brasil - análise of ethnicity variables. Integrated biobehavioral studies employing robust methodologies and applying an ethical approach to research engaging in culturally sensitive strategies should be used to complement surveillance data. The responses to HIV, STIs, and VH in Latin America have rapidly progressed in the last decade, with increased participation of communities in policy action and governance, the expansion and decentralization of health services (including through community-based and peer-led services), and the availability of point-of-care diagnostics and simplified treatments. This new scenario offers opportunities to effectively address prevention and control of communicable diseases in indigenous peoples and Afro-descendants. Nevertheless, to eliminate health access barriers and improve the health outcomes, an intercultural approach to health promotion and service delivery is essential.

Acknowledgments. The authors wish to thank Adele Benzaken and Meritxell Sabidó for sharing their research results prior to publication to allow for their inclusion in this review.

\section{Conflicts of interest. None.}

Disclaimer. Authors hold sole responsibility for the views expressed in the manuscript, which may not necessarily reflect the opinion or policy of the RPSP / PAJPH or the Pan American Health Organization (PAHO).
Geneva: WHO; 2012. Available from: http:/ / www.who.int/reproductivehealth/publications/rtis/2008_STI_estimates.pdf

9. Pan American Health Organization. Hepatitis B and C in the spotlight: a public health response in the Americas, 2016. Washington: PAHO; 2016. Available from: http://iris.paho.org/xmlui/ bitstream/handle/123456789/31449/ 9789275119297-eng.pdf? sequence $=5 \&$ is Allowed $=\mathrm{y}$

10. International Work Group for Indigenous Affairs. IWGIA: regions [Internet]. Copenhagen: IWGIA; 2016 [cited 2016 Dec 8]. Available from: https://www.iwgia.org/ en /indigenous-world/146-english / regions

11. United Nations Development Programme. Afro-descendant population of Latin America II [Internet]. 15 May 2016. New York: UNDP; 2016 [cited 2016 Dec 8] Available from: http://web.archive.org/ 
web /20160515163743/http:/ / afrodescendientes-undp.org/page.php?page= $1 \& l a n g=e n$

12. Organization of American States; InterAmerican Commission on Human Rights. The situation of people of African descent in the Americas. Washington: OAS/IACHR; 2011. (OEA/Ser.L/V/II. Doc. 62). Para. 255; pg. 86. Available from: http://www.oas.org/en/iachr/afro-descendants /docs/pdf/AFROS_2011_ ENG.pdf

13. Inter-American Development Bank. Salud de la mujer indígena. Intervenciones para reducir la muerte materna [Internet]. Washington: IABD; 2010 [cited 2017 Jan 27]. Available from: https://publications. iadb.org/bitstream/handle/11319/246/ Salud\%20de\%201a\%20mujer\%20in$\mathrm{d} \% \mathrm{C} 3 \%$ ADgena.pdf

14. Minority Rights Group International. State of the world's minorities and indigenous peoples. London: Minority Rights Group International; 2013 [cited 2017 Jan 16]. Foreword, p. 7. Available from: http://minorityrights.org/wp-content/ uploads/old-site-downloads / download-1293-State-of-the-Worlds-Minorities-and-Indigenous-Peoples-2013.pdf

15. Gandhi AD, Pettifor A, Barrington C, Marshall SW, Behets F, Guardado ME, et al. Migration, multiple sexual partnerships, and sexual concurrency in the Garífuna population of Honduras. AIDS Behav. 2015;19(9):1559-70. doi: 10.1007/ s10461-015-1139-2

16. Benzaken AS, Sabidó M, Brito I, Bermúdez XPD, Benzaken NS, Galbán E, et al. HIV and syphilis in the context of community vulnerability among indigenous people in the Brazilian Amazon. Int J Equity Health. 2017;16(1):92. doi: $10.1186 /$ s12939-017-0589-8

17. International Labor Organization. Convention on indigenous and tribal peoples, 1989 (no.169): a manual. Geneva: ILO; 2003. ISBN 92-2-113467-9. Available from: http://pro169.org/res/materials/en/ general_resources / Manual $\% 20$ on $\% 20$ ILO \%20Convention\%20No.\%20169.pdf

18. United Nations Economic and Social Council. Permanent Forum on Indigenous Issues, 5th Session: Item 3, Provisional Agenda. Special theme: Millennium Development Goals and indigenous peoples: redefining the Goals: Joint United Nations Programme on HIV/AIDS. E/C.19/2006/6/Add. 10. March 21st 2006. Available from: http://www.unaids.org/sites/default/files/media_asset/unaidsindigenousissuespaper_en_0. pdf

19. United Nations Permanent Forum on Indigenous Issues. The state of the world's indigenous peoples. Indigenous peoples' access to health services. New York: United Nations Department of Economic and Social Affairs, Secretariat of the Permanent Forum on Indigenous Issues; 2015 [cited 2016 Nov 14]. Available from: http://www.un.org/ esa/socdev/unpfii/documents/2015/ sowip2volume-ac.pdf

20. World Health Organization. Global health sector strategy on HIV 2016-2021 towards ending aids. Geneva: WHO; 2016 [cited 2017 Jun 2]. Available from: http://apps. who.int/iris/bitstream/10665/246178/ 1/WHO-HIV-2016.05-eng.pdf

21. World Health Organization. Global health sector strategy on sexually transmitted infections 2016-2021: towards ending STIs. Geneva: WHO; 2016 [cited 2017 Aug 17]. Available from: http://apps.who.int/ iris/bitstream/10665/246296/1/WHORHR-16.09-eng.pdf?ua $=1$

22. World Health Organization. Global health sector strategy on viral hepatitis 2016-2021: towards ending viral hepatitis. Geneva: WHO; 2016 [cited 2017 Aug 17]. Available from: http://apps.who. int/iris/bitstream/10665/246177/1/ WHO-HIV-2016.06-eng.pdf?ua $=1$

23. Pan American Health Organization. Plan of action for the prevention and control of HIV and sexually transmitted infections 2016-2021. Washington: PAHO; 2016 [cited 2017 Jun 2]. Available from: http: / / www.paho.org/hq/index. php?option=com_docman\&task=doc_vi ew\&gid=35735\&Itemid=270\&lang=en

24. Moher D, Liberati A, Tetzlaff J, Altman DG. Preferred reporting items for systematic reviews and meta-analyses: the PRISMA statement. PLoS Med. 2009;6(7): e1000097.

25. Ruffinen CZ, Sabidó M, Díaz-Bermúdez XP, Lacerda M, Mabey D, Peeling RW, et al. Point-of-care screening for syphilis and HIV in the borderlands: challenges in implementation in the Brazilian Amazon. BMC Health Serv Res. 2015;15(495):1-10. doi:10.1186/s12913-015-1155-y

26. Lobo García K, Pinzón J, Ramirez Bedoya B, Garrido VM, Manjarrés Barros VA, Haag Lederer AF. An educational strategy to raise awareness about sexual and reproductive health, HIV/AIDS, aimed at women in a Wayuu indigenous community in Colombia. XVII International AIDS Conference, Mexico City, Mexico, August 3-8, 2008. Abstract No. CDC0922.

27. Rojas C, Castro D, Gómez N, Lozano M, Congote J, Paris S, et al. Prevalence, risk behaviours, and HIV knowledge in an indigenous community in Colombia. Int J Indig Heal. 2015;10(2):102-16.

28. ALAS. Estudio de ITS 2005: métodos y resultados [Internet]. Guatemala: ALAS; 2005 [cited 2016 Nov 8]. Available from: http:/ / www.pasca.org/sites/default/ files $/ 2005 \% 20$ STI $\% 20$ Study $\% 20-\% 20$ Spanish\%20Alas\%20Chimaltenango.pdf

29. Hernández Ayala FM, Ardón E, Farach N, Tinajeros F, Perén J, Guardado ME, et al. Encuesta de vigilancia del comportamiento sexual y prevalencias de infecciones de transmisión sexual y virus de la inmunodeficiencia humana en poblaciones clave de Honduras, 2012 (ECVC). Tegucigalpa: Secretaría de Salud de Honduras; 2014. 176p. Available from: https: / / drive.google.com/file/d/0B p01s2ovIdoVS00MX1HUnZpaVE/ view?ts $=59935902$

30. Ministerio de Salud (HN). Encuesta Centroamericana de vigilancia de comportamiento sexual y prevalencia de VIH e ITS en poblaciones vulnerables: población Garífuna [Internet]. Honduras:
MS; 2008 [cited 2016 Nov 8]. Available from: http://onusida.hn/index.php/ datos-y-analisis/conozca-la-respuesta? showall=\&start $=1$

31. Duque Rodriguez J. Seroprevalence study in Mexico native Indian population. XVII International AIDS Conference, Mexico City, Mexico, August 3-8, 2008. Abstract No. THPE0473.

32. Sipan C, Hovell M, Jimenez-Cruz A, Vera C, Estrada I, Kelley N, et al. Risk behaviors and HIV prevalence in male Mixtec migrant workers in San Quintin, Baja California. XVII International AIDS Conference, Mexico City, Mexico, August 3-8, 2008. Abstract No. TUPE0598.

33. Mendoza L, Mongelos P, Paez M, Castro A, Rodriguez-Riveros I, Gimenez G, et al. Human papillomavirus and other genital infections in indigenous women from Paraguay: a cross-sectional analytical study. BMC Infect Dis. 2013;9(13):531. doi:10.1186/1471-2334-13-531

34. Ministerio de Salud Pública y Bienestar Social (PY). Estudio de prevalencia de sífilis/VIH y conocimientos, prácticas y actitudes de la población indígena en 3 ejes geográficos del Paraguay. Asunción: PRONASIDA; 2011 [cited 2016 Nov 10]. Available from: http://www.pronasida. gov.py/images/documentos/inf_pob_ indigena.pdf

35. Bartlett E, Zavaleta C, Fernández C, Razuri H, Vilcarromero S, Vermund S, et al. Expansion of HIV and syphilis into the Peruvian Amazon: a survey of four communities of an indigenous Amazonian ethnic group. Int J Infect Dis. 2009;12(6):e89-94. doi:10.1016/j.ijid.2008. 03.036

36. Ormaeche M, Whittembury A, Pun M, Suárez-Ognio L. Hepatitis B virus, syphilis, and HIV seroprevalence in pregnant women and their male partners from six indigenous populations of the Peruvian Amazon Basin, 2007-2008. Int J Infect Dis. 2012;16(10):e724-30. doi:10.1016/j. ijid.2012.05.1032

37. PREVEN. Proyecto AMAZON: VIH en la Amazonia Peruana, salud sexual en comunidades indígenas [Internet]. USAID, Pact Brasil; 2007 [cited 2016 Nov 10]. Available from: https:/ / avispasenaccion.wordpress.com / 2008/07/22/ proyecto-preven-y-proyecto-amazon-vih-en-la-amazonia-peruana-resumen-de-resultados-2007/

38. Zavaleta C, Fernández C, Konda K, Valderrama Y, Vermund S, Gotuzzo E. Short report: high prevalence of HIV and syphilis in a remote native community of the Peruvian Amazon. Am J Trop Med Hyg. 2007;76(4):703-5.

39. Zavaleta C, Razuri H, Fernandez C, Lescano A, Bartlett E, Vilcarromero S, et al. HIV and syphilis prevalence in indigenous communities in the Peruvian Amazon: exploring some risk factors. XVII International AIDS Conference, Mexico City, Mexico, August 3-8, 2008. Abstract No. MOPE1079.

40. Villalba JA, Bello G, Maes M, Sulbaran YF, Garzaro D, Loureiro CL, et al. HIV-1 epidemic in Warao Amerindians from Venezuela: spatial phylodynamics and 
epidemiological patterns. AIDS. 2013; 27(11):1783-91. doi:10.1097/QAD.0b013e $3283601 \mathrm{bdb}$

41. Joint United Nations Programme on HIV/ AIDS. UNAIDS: countries [Internet]. Geneva: UNAIDS; 2016 [cited 2016 Nov 15]. Available from: http://www.unaids. org/en/regionscountries/countries

42. World Health Organization. Information note on the use of dual HIV/syphilis rapid diagnostic tests (RDT). Geneva: WHO; 2017 [cited 2017 Aug 13]. Available from: http:/ / apps.who.int/iris/bitstream / 10665/252849/1/WHO-RHR-17.01-eng. pdf?ua $=1$

43. Kim AA, Morales S, Lorenzana de Rivera I, Paredes M, Juarez S, Alvarez B, et al. Short communication: HIV incidence among vulnerable populations in Honduras: results from an integrated behavioral and biological survey among female sex workers, men who have sex with men, and Garifuna in Honduras, 2006. AIDS Res Hum Retroviruses. 2013;29(3):516-9. doi: 10.1089/AID.2012. 0032 Epub 2012 Dec 5.

44. Paz-Bailey G, Morales-Miranda S, Jacobson JO, Gupta SK, Sabin K, Mendoza $S$, et al. High rates of STD and sexual risk behaviors among Garífunas in Honduras. J Acquir Immune Defic Syndr. 2009;51: S26-34.

45. Morales-Miranda S, Paz-Bailey G, Paredes M, Arambu N, Sabin K, Monterroso E. HIV, STD and risk behaviors among men who have sex with men, female sex workers, and indigenous Garífuna population in Honduras. XVII International AIDS Conference, Mexico City, Mexico, August 3-8, 2008. Abstract No. WEAX0305.

46. Farach N, Ardon E, Lorenzana S, Huaman B, Guardado ME, Tinajeros F. Key findings of an HIV bio-behavioral surveillance survey among the Garifuna ethnic minority and its implications for the improvement of HIV prevention programs, Honduras 2012. XX International AIDS Conference: Melbourne, Australia, July 20-25, 2014. Abstract No. PUB042.

47. Medrano J. Vigilancia epidemiológica en Bolivia entre los pueblos originarios. In: Ministerio de Salud y Deportes del Estado Plurinacional de Bolivia; Ministerio de Salud de Peru; UNAIDS; UNICEF; PAHO; FCI, editors. Memoria del encuentro sobre prevención y otros servicios de ITS y VIH dirigidos a pueblos originarios indígenas y amazónicos de Bolivia y Perú. Santa Cruz de la Sierra, Bolivia: August 21-23, 2013. pp. 36-37. Available from: http://bvs.minsa.gob. pe/local/minsa/3019.pdf

48. Vega J. Experiencia del CRVIR41 en tamizaje y consejería en la ciudad de el alto. In: Ministerio de Salud y Deportes del Estado Plurinacional de Bolivia; Ministerio de Salud de Peru; UNAIDS; UNICEF; PAHO, FCI, editors. Memoria del encuentro sobre prevención y otros servicios de ITS y VIH dirigidos a pueblos originarios indígenas y amazónicos de Bolivia y Perú. Santa Cruz de la Sierra, Bolivia: August 21-23, 2013. pp. 67-68. Available from: http://bvs.minsa.gob. pe/local/minsa/3019.pdf
49. Ministerio da Saúde, Secretaria de Vigilância em Saude Program Nacional de DST e AIDS (BR); Santos VL, editors. Distritos sanitários especiais indígenas: diretrizes para implantar o Programa de DST/Aids. Brasília: MS; 2005. 94 p. Available from: http://bvsms.saude.gov. $\mathrm{br} /$ bvs/publicacoes/diret_indigena.pdf

50. Ministerio da Saúde, Secretaría de Vigilancia em Saúde (BR). Boletín epidemiológico SIDA e ITS. Ano VII, No. 01, 2010. Brasília: MS; 2010. Available from: http://bvsms.saude.gov.br/bvs/periodicos/boletim_epidemiologico_sida_ its_v7_n1.pdf

51. Ministerio da Saúde, Secretaría de Vigilancia em Saúde, Departamento de DST, Aids e Hepatites Virais (BR). Boletín epidemiológico Aids e DST. Ano IV No. 0. Brasília: MS; 2015. Available from: http:/ / www.aids.gov.br/pt-br/pub/2015/ boletim-epidemiologico-hivaids-2015

52. Ministerio de Salud y Protección Social de la República, Dirección de Promoción y Prevención (CO); United Nations Population Fund. Convenio 168, componente VIH: panorama del VIH/SIDA en Colombia, 1983-2010. Un análisis de situación. Bogotá: Legis S.A.; 2012. Available from: http://colombia.unfpa.org/sites/ default/files/pub-pdf/PANORAMAVIH-SIDA-COLOMBIA-1983-2010.pdf

53. Garcia J. VIH-VIH avanzado por etnia. Guatemala City: Centro Nacional de Epidemiológia; 2011. Available from: http: / / www.pasca.org / content/ estudios-de-vih-y-poblaciones-ind $\%$ C3\%ADgenas

54. Dirección General de Regulación, Vigilancia y Control de la Salud, Programa Nacional de Prevención y Control de ITS, VIH, y SIDA (GT). Estudio antropológico multicentrico sobre actitudes y prácticas de la población Maya sobre ITS, VIH y Sida y el uso del condón, y estrategias de abordaje sobre sexualidad humana. Guatemala City: DGRVCS; 2010. Available from: http://www.pasca.org/content/ estudios-de-vih-y-poblaciones-in$\mathrm{d} \% \mathrm{C} 3 \%$ ADgenas

55. Dirección General de Regulación, Vigilancia y Control de la Salud, Programa Nacional de Prevención y Control de ITS, VIH, y SIDA (GT); United Nations Population Fund; La Asociación de Investigación Desarrollo y Educación Integral. Estudio antropológico, multiétnico sobre comportamiento, actitudes y prácticas de la población Maya sobre ITS, VIH y SIDA, uso del condón masculino y estrategia de abordaje sobre sexualidad humana. Guatemala City: DGRVCS; 2005. 104p. Available from: http://www.pasca. org / sites / d efault/files / INFORME_ FINAL\%20Estudio $\% 20$ Antropologico $\% 20$ Guatemala.pdf

56. Ministerio de Salud, Comisión Nacional para la Prevención y Control del VIH (PA). Plan estratégico nacional multisectorial de ITS, VIH y Sida: 2009-2014. Panama City: MS; 2009. 108p. Available from: http:/ / www.nationalplanningcycles.org/sites/default/files/planning cycle_repository/panama/hiv_plan_ panama.pdf
57. SEREMI de Salud de Arica y Parinacota, Programa de Salud y Pueblas Indigenas (CL). Situación de salud de la población aymara en la Región de Arica y Parinacota: evidencias de inequidades étnicas en el norte de Chile. SEREMI Salud 2014. 132p. Available from: http:/ / www. seremisalud15.cl/docs/saludPoblacionAymara.pdf

58. Ministerio de Salud y Protección Social (CO). Estudio técnico de servicios diferenciales para los pueblos indígenas de Colombia. Bogotá: Minsalud; 2014. 164p. Available from: https://www.minsalud. gov.co/sites/rid/Lists/BibliotecaDigital/ $\mathrm{RIDE} / \mathrm{VP} / \mathrm{RBC} /$ estudio-suficiencia-indigenas.pdf

59. Instituto Nacional de Estadística y Censo (PA). Estadísticas vitales vol. III - defunciones, con información concerniente a los hechos ocurridos en la República, en el 2014. Panama: INEC; 2014. Available from: http://www.contraloria.gob.pa/ INEC / Publicaciones / Publicaciones. aspx?ID_SUBCATEGORIA=7\&ID_ P U B L I C A C I O N = 708 \& I D _ IDIOMA $=1 \&$ ID CATEGORIA $=3$

60. Ferri K, Gomes AM. Doenças sexualmente transmissíveis e aids entre indígenas do Distrito Sanitário Especial Indígena do Mato Grosso do Sul de 2001 a 2005. Saude Coletiva. 2011;8(47):7-12.

61. Departamento Administrativo Nacional Estadística (CO). La visibilización estadística de los grupos étnicos colombianos. Bogota: DANE; 2006 [cited 2016 Dec 9]. Available from: https://www. dane.gov.co/files/censo2005/etnia/ sys/visibilidad_estadistica_etnicos.pdf

62. Díaz-Olavarrieta C, Wilson KS, García SG, Revollo R, Richmond K, Paz F, Chavez LP. The co-occurrence of intimate partner violence and syphilis among pregnant women in Bolivia. J Womens Health 2009;18(12):2077-86. doi: 10.1089/jwh. 2008.1258

63. Benzaken AS, Sardinha JCG, Garcia EG. Sífilis congênita en comunidades indígenas de difícil acceso: desafio a superar mediante uso de la tecnologia. Rev Leprologia Fontilles. 2010;17:551-60.

64. de Souza VA, Sumita LM, Nascimento MC, Oliveira J, Mascheretti M, Quiroga $\mathrm{M}$, et al. Human Herpesvirus-8 Infection and oral shedding in amerindian and non-amerindian populations in the Brazilian Amazon region. J Infect Dis. 2007;196(6):844-52. doi:10.1086/520549

65. Pan American Health Organization. Elimination of mother-to-child transmission of HIV and syphilis in the Americas: update 2015. Washington: PAHO; 2015 [cited 2017 Aug 8]. Available from: http:/ / iris.paho.org/xmlui/bitstream/handle/123456789/18372/9789275118702 eng.pdf? sequence $=3 \&$ isAllowed $=y$

66. Domingues RMSM, Szwarcwald CL, Souza Junior PRB, Leal M do C. Prevalence of syphilis in pregnancy and prenatal syphilis testing in Brazil: birth in Brazil study. Rev Saude Publica. 2014;48(5):774 doi:10.1590/S0034-8910.2014048005114.

67. Instituto Nacional de Salud; Folleco AE. Informe final hepatitis A, Colombia 2013. Bogotá: INS; 2013. 23p. 
68. Kozlowski AG, Motta-Castro AR, Nascimento LB, Silva AM, Teles SA, Villar LM, et al. Prevalence of hepatitis A virus infection in Afro-Brazilian isolated communities in Central Brazil. Mem Inst Oswaldo Cruz, Rio de Janeiro. 2007;102(1):121-3.

69. Alvarado-Mora MV, Botelho L, Nishiya A, Neto RA, Gomes Gouvea MS, Gutierrez MF, et al. Frequency and genotypic distribution of GB virus C (GBV-C) among Colombian population with hepatitis B (HBV) or hepatitis C (HCV) infection. Virol J. 2011;8(1):345-51. doi: 10.1186/1743-422X-8-345

70. Delfino CM, Berini C, Eirin ME, Malan R, Pedrozo W, Krupp R, et al. New natural variants of hepatitis $B$ virus among amerindians from Argentina with mainly occult infections. J Clin Virol. 2012;54(2): 174-9. doi:10.1016/j.jcv.2012.02.023

71. Ferreira A, Greca D, Tavares E, Moriya Y, Spelling F, Boeira $\mathrm{M}$, et al. Soroepidemiologia da hepatite B e C em índios Kaingang do Sul do Brasil. Rev Panam Salud Publica. 2006;20(4):230-5.

72. Nunes HM, Monteiro MRCC, Soares MCP. Prevalence of hepatitis B and D serological markers in the Parakanã, Apyterewa Indian Reservation, Pará State, Brazil. Cad Saúde Pública. 2007;23(11):2767-79.

73. Alvarado-Mora M V, Botelho L, GomesGouvêa MS, de Souza VF, Nascimento MC, Pannuti CS, et al. Detection of hepatitis B virus subgenotype A1 in a Quilombo community from Maranhão, Brazil. Virol J. 2011;8(1):415-20. doi:10. 1186/1743-422X-8-415

74. Viana S, Parana R, Moreira RC, Compri AP, Macedo V. High prevalence of hepatitis $B$ virus and hepatitis $D$ virus in the western Brazilian Amazon. Am J Trop Med Hyg. 2005;73(4):808-14.

75. Matos MAD, Reis NRS, Kozlowski AG, Teles SA, Motta-Castro AR, Mello FCA, et al. Epidemiological study of hepatitis A, $\mathrm{B}$ and $\mathrm{C}$ in the largest Afro-Brazilian isolated community. Trans R Soc Trop Med Hyg. 2009;103(9):899-905. doi:10.1016/j. trstmh.2009.01.013

76. Motta-Castro ARC, Martins RMB, Araujo NM, Niel C, Facholi GB, Lago BV, et al. Molecular epidemiology of hepatitis B virus in an isolated Afro-Brazilian community. Arch Virol. 2008;153(12):2197205. doi:10.1007/s00705-008-0237-0

77. Motta-Castro ARC, Martins RMB, Yoshida CFT, Teles SA, Paniago AM, Lima KMB, et al. Hepatitis B virus infection in isolated Afro-Brazilian communities. J Medical Virology. 2005;77(2):188-93. doi: 10.1002/ jmv.20435

78. Motta-Castro ARC, Yoshida CFT, Lemos ERS, Oliveira JM, Cunha RV, LewisXimenez LL, et al. Seroprevalence of hepatitis B virus infection among an Afrodescendant community in Brazil. Mem Inst Oswaldo Cruz. 2003;98(1):13-7.

79. Alvarado-Mora MV, Gutierrez Fernandez MF, Gomes-Gouveia MS, de Azevedo Neto RS, Carrilho FJ, Rebello Pinho JR. Hepatitis B (HBV), hepatitis C (HCV) and hepatitis delta (HDV) viruses in the Colombian population: how is the epidemiological situation? PLoS ONE. 2011; 6(4):e18888. doi:10.1371/journal.pone. 0018888

80. di Filippo Villa D, Cortes-Mancera F, Payares E, Montes N, de la Hoz F, Arbelaez MP, et al. Hepatitis D virus and hepatitis $B$ virus infection in amerindian communities of the Amazonas state, Colombia. Virol J. 2015;12(1):172. doi:10. 1186/s12985-015-0402-5

81. Roman S, Tanaka Y, Khan A, Kurbanov F, Kato H, Mizokami M, et al. Occult hepatitis B in the genotype H-infected Nahuas and Huichol native Mexican population. J Med Virol. 2010;82:1527-36. doi:10.1002/ jmv.21846

82. Duarte MC, Cardona N, Poblete F, González K, García M, Pacheco M, et al. A comparative epidemiological study of hepatitis B and hepatitis D virus infections in Yanomami and Piaroa Amerindians of Amazonas State, Venezuela. Trop Med Int Health. 2010;15(8):924-33. doi:10.1111/ j.1365-3156.2010.02560.x

83. Monsalve-Castillo F, Echevarría JM, Atencio R, Suárez A, Estévez J, CostaLeón $\mathrm{L}$, et al. Alta prevalencia de la infección por el virus de hepatitis B en la comunidad indígena Japreira, Estado Zulia, Venezuela. Cad Saude Publica. 2008;24(5):1183-6.

84. Rovira C, Monzón I, Almirón M. Hepatitis virales en diferentes grupos étnicos del Paraguay. Mem Inst Invest Cienc Salud. 2005;3(1):5-8.

85. Cabezas Sánchez C, Trujillo Villarroel O, Zavaleta Cortijo C, Culqui Lévano D, Suarez Jara M, Cueva Maza N, et al. Prevalencia de la infección por el virus de hepatitis B en niños menores de 5 años de comunidades indígenas de la Amazonía peruana posterior a intervenciones mediante inmunización. Rev Peru Med Exp Salud Publica. 2014;31(2):204-10.

86. Reis NR, Motta-Castro AR, Silva AM, Teles SA, Yoshida CF, Martins RM. Prevalence of Hepatitis $C$ virus infection in Quilombo remnant communities in Central Brazil. Rev Inst Med Trop Sao Paulo. 2008;50(6):359-60.

87. De León Richardson RG, García LM, Chu EE, Mendoza AI, Mojica FC, et al. Encuesta nacional de salud sexual y reproductiva 2009: informe final. Panamá: Instituto Conmemorativo Gorgas de Estudios de la Salud; 2011. 372p. Available from: http://www.contraloria. gob.pa/inec/Aplicaciones/ENASER/ EnasserInformeFinal.pdf

88. Contraloría General de la República, Instituto Nacional de Estadística y Censo, Programa Global de MICS (PA) Encuesta de indicadores múltiples por conglomerados de Panamá 2013, resultados principales. Panamá: Contraloría General; 2014. Available from: https:// www.contraloria.gob.pa/inec/archivos/MICS_FINAL.pdf

89. Rodriguez L, Vázquez $M$, Rojo $M$, Argañaraz V, Gareca F, Romeo M. HIV vulnerability of indigenous people in the Northwestern Argentina. XVIII International AIDS Conference, Vienna, Austria, July 18-23. Abstract No. WEPE0384.

90. Orellana ER, Alva IE, Carcamo C, Canchihuaman F, Bernabe A, Cotrina A, et al. HIV and other sexually transmitted infections among indigenous populations in the Peruvian Amazon. XVII International AIDS Conference, Mexico City, Mexico, August 3-8, 2008. Abstract No. MOPE0355.

91. Jacobson J, Paz-Bailey G, Hidalgo E, Monterros E. Nationally representative estimates of HIV/AIDS knowledge, risk behaviors, and associated demographic factors among women in Guatemala, 2002. XVII International AIDS Conference, Mexico City, Mexico, August 3-8, 2008. Abstract No. TUPE0261.

92. Stansbury JP, Sierra M. Risks, stigma and Honduran Garífuna conceptions of HIV / AIDS. Soc Sci Med. 2004;59(3):45771. doi:10.1016/j.socscimed.2003.11.013

93. Programa Nacional de Lucha Contra los RH, SIDA y ETS (AR); Sotelo JA, Ferrero LM, editors. Estudio sobre comportamiento e información en relación con el VIH/SIDA e Its en poblaciones aborígenes de Argentina. Buenos Aires: Programa Nacional de Lucha Contra los RH, SIDA y ETS; 2005. doi:10.1017/ CBO9781107415324.004

94. Mendizabal-Burastero R, Yancor MP. HIV in indigenous MSM in Guatemala: a hidden problem. Sex Transm Infect. 2017; 93(S2):A1641.

95. Pan American Health Organization. Policy on ethnicity and health. 29 ${ }^{\text {th }}$ Pan American Sanitary Conference, Washington, D.C., USA, 25-29 September 2017. (CSP29/7). Available from: https://www.paho.org/ hq/index.php?option $=$ com_content\& view $=$ article $\& i d=13497 \&$ Itemid $=2105 \&$ lang=es

96. Knipper M. Beyond the indigenous: health and interculturality at the global level. Rev Peru Med Exp Salud Publica. 2010;27(1):94-101.

97. Pan American Health Organization. Policy on ethnicity and health. 160th Session of the Executive Committee, Washington, D.C., USA, 26-30 June 2017. (CE160/15). Available from: http://iris.paho.org/xmlui/handle/123456789/34195

98. Álvarez AMR, Pérez-Vilar S, Pacis-Tirso C, Contreras M, El Omeiri N, Ruiz-Matus $\mathrm{C}$, et al. Progress in vaccination towards hepatitis B control and elimination in the Region of the Americas. BMC Public Health. 2017;17:325. doi 10.1186/ s12889-017-4227-6

Manuscript submitted 16 January 2018. Revised version accepted for publication on 25 June 2018. 
RESUMEN

Infección por el VIH, sífilis y
hepatitis virales en las
poblaciones indígenas y
afrodescendientes en
América Latina: una
revisión sistemática

Objetivo. Identificar y resumir la bibliografía existente sobre la carga de la infección por el VIH, las infecciones de transmisión sexual (ITS) y las hepatitis virales en las poblaciones indígenas y afrodescendientes en América Latina para proporcionar un panorama amplio de los datos cuantitativos disponibles y poner de relieve las brechas problemáticas que pudiera haber en los datos.

Métodos. Se hizo un examen sistemático de la bibliografía publicada y la bibliografía gris para encontrar documentos publicados en inglés, español o portugués con datos recogidos entre enero del 2000 y abril del 2016 sobre la carga de la infección por el VIH, las ITS y las hepatitis virales en las poblaciones indígenas y afrodescendientes en 17 países latinoamericanos.

Resultados. Se encontraron 62 documentos de 12 países. La prevalencia de la infección por el VIH fue generalmente baja $(<1 \%)$, pero se observaron focos de prevalencia alta $(>5 \%)$ en algunas comunidades indígenas en Venezuela (Warao) $(9,6 \%)$, Perú (Chayahuita) (7,5\%) y Colombia (las mujeres Wayuus) (7,0\%). Se observó prevalencia alta de sífilis activa (> 5\%) en algunas comunidades indígenas en Paraguay $(11,6 \%$ y $9,7 \%)$ y Perú (Chayahuita) $(6,3 \%)$. Se encontró endemicidad alta $(>8 \%)$ de la hepatitis B en algunos pueblos indígenas en México (Huichol) $(9,4 \%)$ y Venezuela (Yanomami: 14,3\%; Japreira: 29,5\%) y en las poblaciones quilombola de afrodescendientes en Brasil (Frechal: 12,5\%; Furnas do Dionísio: 8,4\% en el 2008, 9,2\% en el 2003).

Conclusiones. Las brechas en los datos existentes sobre la carga de la infección por el $\mathrm{VIH}$, las ITS y las hepatitis virales en las poblaciones indígenas y afrodescendientes en América Latina destacan la necesidad de: 1) mejorar la vigilancia nacional mediante la recolección y el análisis sistemáticos de las variables de etnicidad y la ejecución de estudios bioconductuales integrados que utilicen metodologías sólidas y estrategias sensibles a diferencias entre las culturas; 2) elaborar una política de respuesta de alcance regional que considere las necesidades de las poblaciones indígenas y de afrodescendientes; y 3) aplicar un enfoque intercultural de la salud y de la prestación de servicios conexos para eliminar las barreras de acceso a la salud y mejorar los resultados en materia de salud para estas poblaciones.

Palabras clave VIH; enfermedades de transmisión sexual; sífilis; hepatitis viral humana; salud de poblaciones indígenas; América Latina. 
RESUMO

\section{HIV, sífilis e hepatite viral em povos indígenas e afrodescendentes da América Latina: uma revisão sistemática}

Palavras-chave
Objetivo. Identificar e sintetizar a literatura existente sobre a carga de HIV, infecções sexualmente transmissíveis (IST) e hepatite viral nos povos indígenas e afrodescendentes da América Latina para traçar um amplo panorama dos dados quantitativos disponíveis e destacar as lacunas problemáticas nos dados.

Métodos. Foi realizada uma revisão sistemática da literatura publicada e da literatura cinzenta para identificar documentos publicados em inglês, espanhol ou português com dados coletados entre janeiro de 2000 e abril de 2016 sobre a carga de HIV, IST e hepatite viral nos povos indígenas e afrodescendentes em 17 países latino-americanos.

Resultados. Sessenta e dois documentos de 12 países foram encontrados. A prevalência de HIV observada foi em geral baixa $(<1 \%)$, com focos de alta prevalência $(>5 \%)$ observados em comunidades indígenas da Venezuela (warao) $(9,6 \%)$, Peru (chayahuita) $(7,5 \%)$ e Colômbia (mulheres wayúu) $(7,0 \%)$. Foi verificada uma alta prevalência de sífilis ativa (> 5\%) em comunidades indígenas no Paraguai (11,6\% e 9,7\%) e Peru (chayahuita) $(6,3 \%)$. A alta endemicidade $(>8 \%)$ de hepatite B foi observada em povos indígenas no México (huichol) (9,4\%) e Venezuela (ianomâmi 14,3\%; japrería 29,5\%) e em comunidades negras quilombolas no Brasil (Frechal 12,5\%; Furnas do Dionísio $8,4 \%$ em 2008 e $9,2 \%$ em 2003).

Conclusões. As lacunas nos dados existentes sobre a carga de HIV, IST e hepatite viral nos povos indígenas e afrodescendentes na América Latina destacam a necessidade de: melhorar a vigilância nacional com coleta sistemática e análise de variáveis de etnicidade e realizar estudos integrados de análise biocomportamental com o uso de metodologias robustas e estratégias sensíveis à diversidade cultural; desenvolver uma política de resposta regional que considere as necessidades dos povos indígenas e afrodescendentes; e implementar um enfoque intercultural à saúde e prestação de serviços para derrubar as barreiras de acesso à saúde e melhorar os resultados de saúde nestas populações.

HIV; doenças sexualmente transmissíveis; sífilis; hepatite viral humana; saúde de populações indígenas; América Latina. 